\title{
Soil-applied Zn effect on soil fractions
}

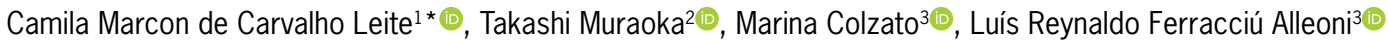

\begin{abstract}
${ }^{1}$ Universidade de São Paulo/EESC - Depto. de Engenharia Hidráulica e Saneamento, Av. Trabalhador São Carlense, 400 - 13566-590 - São Carlos, SP - Brasil.

2Universidade de São Paulo/CENA - Lab. de Fertilidade do Solo, Divisão de Produtividade Agroindustrial e Alimentos, Av. Centenário, 303 - 13416-000 - Piracicaba, SP - Brasil. 3Universidade de São Paulo/ESALQ - Depto. de Ciência do Solo, Av. Pádua Dias, 11 - 13418-900 - Piracicaba, SP Brasil.

${ }^{*}$ Corresponding author <camilamcleite@gmail.com>
\end{abstract}

Edited by: Francesco Montemurro

Received April 26, 2018

Accepted September 24, 2018
ABSTRACT: The interaction of $\mathrm{Zn}$ with soil compartments influences its bioavailability and uptake by plants. In this study, rice and soybean were cultivated under greenhouse conditions with the aim of evaluating $\mathrm{Zn}$ bioavailability and fractionation in a clayey-textured Typic Hapludox as a function of $\mathrm{Zn}$ rates ( 4 or $8 \mathrm{mg} \mathrm{kg}^{-1} \mathrm{Zn}$ ). The experiment was conducted until grain filling. Two soil subsamples $\left(t_{1}\right.$ and $\left.t_{2}\right)$ that referred to the seeding and flowering stages, were collected and compared with two single extraction schemes, DTPA $\left(\mathrm{Zn}_{\text {DTPAt1 }}\right.$ and $\left.\mathrm{Zn}_{\text {DTPAt }}\right)$ and Mehlich-1 $\left(\mathrm{Zn}_{\text {Mt1 }}\right.$ and $\left.Z n_{\text {Mt2 }}\right)$ for $Z n$ available contents. $Z n$ fractionation was carried out with $t_{2}$ soil subsamples for the testing of the following fractions: exchangeable $Z n\left(Z n_{E x C}\right), Z n$ bound to carbonates $\left(Z n_{\text {Carb }}\right), Z n$ bound to organic matter $\left(Z n_{\text {om }}\right), Z n$ bound to oxides $\left(Z n_{0 x i}\right)$ and residual $Z n\left(Z n_{\text {res }}\right)$. $Z n$ applied to soil increased the $\mathrm{Zn}$ concentration in labile fractions in decreasing order as follows: $Z \mathrm{n}_{\mathrm{ExC}}>\mathrm{Zn}_{\mathrm{OM}}>$ $Z n_{\text {carb }}$. There was no difference between the lesser or unavailable fractions, $Z n_{\text {oxi }}$ and $Z n_{\text {res, }}$, when there was no correlation between the rates either with total accumulated $\mathrm{Zn}$ in plants $\left(\mathrm{Zna}_{\text {total }}\right)$, or the contents extracted by DTPA or Mehlich-1. Total cumulative Zn content in rice and soybean affected by the $\mathrm{ZnCl}_{2}$ rates applied were positively correlated with $\mathrm{Zn}$ content extracted by both solutions. Both extractant solutions presented positive correlation between available contents of $\mathrm{Zn}$ with $\mathrm{Zn}$ bound to labile fractions.

Keywords: DTPA, Mehlich-1, soil phases, soil chemistry, micronutrient

\section{Introduction}

Zinc $(\mathrm{Zn})$ participates in biogeochemical processes in soil, sediments, and aquatic settings (Cloquet et al., 2008), but is the most widespread in terms of deficiency in micronutrients for a number of crops all over the world (Dobermann and Fairhust, 2000). The dynamics of $\mathrm{Zn}$ in soil-plant systems have important economic and environmental implications, as $\mathrm{Zn}$ is a bioessential element for the growth and reproduction of living organisms (Frassinetti et al., 2006). Its behavior in the soil is complex because it depends on the dynamics of the soil compounds (Alexakis, 2011), whose heterogeneity enables its presence in several forms, whether soluble or weak or as $\mathrm{Zn}$ bound to soil particles (Abreu et al., 2007).

Zn bioavailability and remobilization are readily modified by environmental conditions. Physical and chemical variations can significantly change the balance reactions between the soil solution and organic or inorganic fractions (Gismera et al., 2004; Tessier et al., 1979). A deep understanding of $\mathrm{Zn}$ chemical reactions within soil components and its geochemical behavior are fundamental to the characterization of nutrient availability to plants. $\mathrm{Zn}$ is sorbed mainly to organic matter, oxides and carbonates, which can be conceptually determined by sequential extractions to obtain the sorbed $\mathrm{Zn}$ distributed in acid soluble, reducible, oxidisable and residual fractions present in the soil (Rauret et al., 1999). Its distribution in each fraction depends on the soil organic matter content, $\mathrm{pH}$, temperature (Tiller et al., 1984), texture, structure, amount and type of clay minerals (Spark and Wells, 1995), cation exchange properties, metal oxide fractions (Stahl and James, 1991;
Guadalix and Pardo, 1995) and transformations in the source material (Fontes and Alleoni, 2006). The total Zn in the soil does not represent the $\mathrm{Zn}$ bioavailability properly, since the available Zn easily interacts in chemical reactions, which varies according to the soil physical or chemical characteristics and water parameters resulting in a temporary increasing in available $\mathrm{Zn}$ followed by a decreasing in available $\mathrm{Zn}$ for plants (Impa et al., 2012). Therefore, the $\mathrm{Zn}$ distribution must be distinguished between the fractions of soil.

This study addresses an evaluation of $\mathrm{Zn}$ bioavailability to rice (Oryza sativa L.) and soybean (Glycine max L. Merrill) and its fractionation in a clayey-textured soil as a function of soil-applied $\mathrm{Zn}$ rates.

\section{Materials and Methods}

\section{Soil samples}

The $\mathrm{Zn}$ fractionation in soil was evaluated in a typical low Zn-content humid tropical soil. Surface 10-20 $\mathrm{cm}$ ) samples of a clayey-textured Typic Hapludox (Soil Survey Staff, 1999) were collected from a field near Piracicaba $\left(22^{\circ} 42^{\prime} 30^{\prime \prime} \mathrm{S}, 47^{\circ} 38^{\prime} 00^{\prime \prime} \mathrm{W}\right.$; altitude: $\left.546 \mathrm{~m}\right)$ in the state of São Paulo (SP), Brazil. Soil samples were airdried, crushed and sieved through a $2 \mathrm{~mm}$ screen.

Chemical and physical characterizations were conducted according to van Raij et al. (2001) and Camargo et al. (1986), respectively (Table 1). The determination of potentially available $\mathrm{Zn}$ content was conducted using 20 g of dry soil sample, which was extracted with $40 \mathrm{~mL}$ of a DTPA solution and the concentration determined by flame atomic absorption spectrophotometry (FAAS) as described in the Chemical Analysis Manual for Tropical Soils (van Raij et al., 2001). 
Table 1 - Chemical and physical properties of soil studied. Data reported as a mean of triplicate determinations, except for unreplicated textural determinations.

\begin{tabular}{lr}
\hline Parameters (unit) & Value \\
\hline $\mathrm{pH}\left(0.01 \mathrm{~mol} \mathrm{~L}^{-1} \mathrm{CaCl}_{2}\right)$ & 3.8 \\
$\mathrm{P}\left(\mathrm{mg} \mathrm{dm}^{-3}\right)$ & 7 \\
$\mathrm{~K}\left(\mathrm{mmol}_{\mathrm{c}} \mathrm{dm}^{-3}\right)$ & 1.5 \\
$\mathrm{Ca}\left(\mathrm{mmol}_{\mathrm{c}} \mathrm{dm}^{-3}\right)$ & 4 \\
$\mathrm{Mg}\left(\mathrm{mmol}_{\mathrm{c}} \mathrm{dm}^{-3}\right)$ & 2 \\
$\mathrm{H}+\mathrm{Al}\left(\mathrm{mmol}_{\mathrm{c}} \mathrm{dm}^{-3}\right)$ & 82 \\
$\mathrm{BS}$ ( $\left.\mathrm{mmol}_{\mathrm{c}} \mathrm{dm}^{-3}\right)$ & 7.5 \\
$\mathrm{CEC}\left(\mathrm{mmol}_{\mathrm{c}} \mathrm{dm}^{-3}\right)$ & 90.2 \\
$\mathrm{~V}_{\mathrm{c}}(\%)$ & 9 \\
$\mathrm{Na}\left(\mathrm{mg} \mathrm{dm}^{-3}\right)$ & 4.5 \\
$\mathrm{Si}\left(\mathrm{mg} \mathrm{dm}^{-3}\right)$ & 6.3 \\
$\mathrm{Zn}\left(\mathrm{mg} \mathrm{dm}^{-3}\right)$ & 0.7 \\
$\mathrm{Cu}\left(\mathrm{mg} \mathrm{dm}^{-3}\right)$ & 0.9 \\
$\mathrm{Fe}\left(\mathrm{mg} \mathrm{dm}^{-3}\right)$ & 60.3 \\
Mn $\left(\mathrm{mg} \mathrm{dm}^{-3}\right)$ & 7.7 \\
WHC $\left(\mathrm{g} \mathrm{dm}^{-3}\right)$ & 168.3 \\
OMe $\left(\mathrm{g} \mathrm{dm}^{-3}\right)$ & 26 \\
Sand $\left(\mathrm{g} \mathrm{dm}^{-3}\right)$ & 546 \\
Silt $\left(\mathrm{g} \mathrm{dm}^{-3}\right)$ & 83 \\
Clay $\left(\mathrm{g} \mathrm{dm}^{-3}\right)$ & 371 \\
\hline
\end{tabular}

Notes: ${ }^{\mathrm{B} B S}=$ sum of basis; ${ }^{\mathrm{b}} \mathrm{CEC}=$ cation exchange capacity; ${ }^{\mathrm{C} V}=$ percentage of soil base saturation; ' $\mathrm{WHC}=$ water-holding capacity; ${ }^{\mathrm{e}} \mathrm{OM}=$ organic matter.

\section{Zn uptake experiment}

The effects of $\mathrm{Zn}$ on the soil and its bioavailability were evaluated in a greenhouse experiment. Three $\mathrm{kg}$ of air-dried and sieved soil samples were placed in 4 $\mathrm{dm}^{3}$ plastic pots. The soil samples' base saturation was raised to $50 \%$ for rice and $60 \%$ for soybean crops by liming (Cantarella and Furlani, 1997; Trani and van Raij, 1997). The samples were homogenized and incubated for 30 days and $70 \%$ of the water-holding capacity of the soil was maintained. A $\mathrm{ZnCl}_{2}$ solution was added at the rates of 4 and $8 \mathrm{mg} \mathrm{kg}^{-1}$, in four replicates and two crops (rice and soybean), which gave a total of 24 experimental units; including 4 control samples $10 \mathrm{mg} \mathrm{kg}^{-1}$ of $\mathrm{Zn}$ added). These rates were selected according to Novais et al. (1991) for basic fertilization in controlled condition experiments ( $\mathrm{Zn}$ recommendation - $4 \mathrm{mg} \mathrm{kg}^{-1}$ ). The samples were watered with deionized water $170 \%$ water-holding capacity - WHC) for two days to achieve $\mathrm{Zn}$ equilibrium in the soil.

Rice seeds from the IAC-203/Mococa-13 cultivar or soybean seeds of UFV-16/Capinópolis cultivar were used at a seven seed per pot rate from the growth period to grain filling. Both crops carry a certain social importance since they are the usual sources of carbohydrate and protein for the human diet; mainly in developing countries. In addition, rice and soybean are fundamental to the national economy in terms of agricultural activities.

All treatments were fertilized in two steps; the first one on the same day of sowing and the second, one month after the first germination. The nutritive solution was composed of $\mathrm{N}\left(250 \mathrm{mg} \mathrm{dm}^{-3}: 59.48 \mathrm{mg} \mathrm{dm}^{-3}\right.$, as urea; $155.52 \mathrm{mg} \mathrm{dm}^{-3}$, as monopotassium phosphate MAP, and $35.00 \mathrm{mg} \mathrm{dm}^{-3}$, as ammonium sulphate - AS), $\mathrm{P}\left(297.00 \mathrm{mg} \mathrm{dm}^{-3}\right.$ as MAP), $\mathrm{K}\left(95.26 \mathrm{mg} \mathrm{dm}^{-3}\right.$ as $\left.\mathrm{KCl}\right)$, $\mathrm{S}$ (40.00 $\mathrm{mg} \mathrm{dm}^{-3}$ as AS), B (0.60 $\mathrm{mg} \mathrm{dm}^{-3}$ as boric acid), $\mathrm{Cu}\left(0.60 \mathrm{mg} \mathrm{dm}^{-3}\right.$ as copper sulphate) and Mo (0.15 mg $\mathrm{dm}^{-3}$ as molybdic acid), according to recommendations by Malavolta (1980) and Novais et al. (1991). The soil moisture content was watered down to $70 \%$ WHC applied in the surface soil and two soil subsamples $/ t_{1}$ and $\mathrm{t}_{2}$ ) were collected in the seeding and flowering stages, respectively.

The plants were cultivated up to the physiological maturity of the grains, i.e. 98 days after germination for soybean and 108 days for rice. The stems were cut approximately $0.5 \mathrm{~cm}$ above the soil surface and the vegetable samples dried in a forced circulation oven at $65^{\circ} \mathrm{C}$ for $72 \mathrm{~h}$. After drying, the samples were weighed to obtain the dry matter. Total $\mathrm{Zn}$ content in the plant subsamples $\left(\mathrm{Zna}_{\text {total }}\right)$ for both crops was determined after nitro-perchloric digestion (Miyazawa et al., 2009) in the plant subsamples by multiplying the total $\mathrm{Zn}$ content by the weight of the dry matter.

\section{Zn extraction procedures Single extractions}

Representative soil samples of each vessel in $t_{1}$ and $t_{2}$ sampling periods were extracted by two chemical reagents (DTPA and Mehlich-1) for evaluating the available fraction. Both extractants are widely used; DTPA is a stable chelating agent, while Mehlich-1 has an acid character. Although micronutrient extraction by DTPA is a widespread procedure, here we compared it with Mehlich-1.

Dry soil (20 g) comprised extracted solution mixed with $40 \mathrm{~mL}$ of $0.005 \mathrm{M}$ diethylenetriaminepentaacetic acid (DTPA) in $0.01 \mathrm{~mol} \mathrm{~L}^{-1} \mathrm{CaCl}_{2}$ buffered at $\mathrm{pH} 7.3$ with $0.1 \mathrm{~mol} \mathrm{~L}^{-1}$ triethanolamine (TEA), at room temperature, and shaken for $2 \mathrm{~h}$ (Lindsay and Norvell, 1978). Another three grams ( $3 \mathrm{~g}$ ) were mixed with $15 \mathrm{~mL}$ of a Mehlich-1 extractant solution $\left(\mathrm{HCl} 0.05 \mathrm{~mol} \mathrm{~L}{ }^{-1}+\mathrm{H}_{2} \mathrm{SO}_{4} 0.0125\right.$ mol L-1), at room temperature, and shaken for $5 \mathrm{~min}$ (Embrapa, 1997). The resulting mixture was filtered at $0.45 \mu \mathrm{m}$ and the filtrate was determined by FAAS so as to obtain the following extracted $\mathrm{Zn}$ parameters: $\mathrm{Zn}_{\text {DTPAt1 }}$, $\mathrm{Zn}_{\text {DTPAt2 }}, \mathrm{Zn}_{\mathrm{Mt1}}$ and $\mathrm{Zn}_{\mathrm{Mt} 2}$.

\section{Zn fractionation in soil}

Zn was sequentially extracted from soil compartments for the purpose of assessing $\mathrm{Zn}$ fractions (phases). The method developed by Silveira et al. (2006) calibrated for tropical soil conditions was selected from among the several fractionation procedures for estimating the extractable metal pools as regards metal-bearing soil phases (Alloway, 1995; Asami et al., 1995; Cabral and Lefebvre, 1998; Rauret et al., 1999; Tessier et al., 1979). A five-stage sequential scheme was implemented with 
$1 \mathrm{~g}$ of $\mathrm{t}_{2}$ soil subsampling from each experimental unit (Table 2). Such a subsample is justified by the flowering stage, which enables correlation of the highest absorbed concentration of nutrients by plants.

Exchangeable $\mathrm{Zn}\left(\mathrm{Zn}_{\mathrm{Exc}}\right)$ and $\mathrm{Zn}$ bound to carbonate $\left(\mathrm{Zn}_{\text {Carb }}\right)$, organic matter $\left(\mathrm{Zn}_{\mathrm{OM}}\right)$, oxides $\left(\mathrm{Zn}_{\mathrm{Oxi}}\right)$ and residual phases $\left(\mathrm{Zn}_{\text {res }}\right)$ were determined. The same soil subsamples were used in the development of the fractions by distinct processes and under different conditions. Additionally, pseudo-total $\mathrm{Zn}\left(\mathrm{Zn}_{\mathrm{PST}}\right)$, was determined by the same method used for $\mathrm{Zn}_{\text {res }}$ by microwave-assisted acid digestion with $\mathrm{HNO}_{3}+\mathrm{HCl}$, as described by the USEPA 3051A methodology. All concentration was determined by FAAS and the sum of extracted $\mathrm{Zn}\left(\mathrm{Zn}_{\mathrm{suM}}\right)$ and Recovery (Rec) was calculated by equations 1 and 2 .

$\mathrm{Zn}_{\mathrm{SUM}}=\mathrm{Zn}_{\mathrm{Exc}}+\mathrm{Zn}_{\mathrm{Carb}}+\mathrm{Zn}_{\mathrm{OM}}+\mathrm{Zn}_{\mathrm{Oxi}}+\mathrm{Zn}_{\text {res }}$

$\operatorname{Rec}(\%)=\frac{Z_{\text {SUM }}}{Z_{n_{\text {PST }}}} \times 100$

\section{Statistical analysis}

The experiment was conducted in a factorial design between three $\mathrm{ZnCl}_{2}$ rates $\left(0,4\right.$ and $\left.8 \mathrm{mg} \mathrm{kg}^{-1}\right)$ and two crops, with four replications distributed in a completely randomized design for both crops. Averages and standard deviations of the replicate data were calculated and the significance of treatment factors was assessed by analysis of variance (ANOVA) using statistical software (SAS - Statistical Analysis System, v. 9.4). Treatment averages were compared by Tukey's significant difference procedure $(p<0.05)$ for detecting differences in the $\mathrm{Zn}$ fractions. Data behaviors were represented by fitting regression models using SigmaPlot software. After the descriptive analysis of the response variables, a Pearson's correlation analysis was performed to assess the contribution among $\mathrm{Zn}$ fractions in the soil $\left(\mathrm{Zn}_{\mathrm{Exc}^{\prime}} \mathrm{Zn}_{\mathrm{Carb}^{\prime}}\right.$ $\mathrm{Zn}_{\mathrm{OM}}, \mathrm{Zn}_{\mathrm{Oxi}}$ and $\left.\mathrm{Zn}_{\text {res }}\right)$ and other variables $\left(\mathrm{Zna}_{\text {total }} \mathrm{Zn}_{\mathrm{PST}^{\prime}}\right.$ $\mathrm{Zn}_{\text {DTPAt1 }}, \mathrm{Zn}_{\text {DTPAt } 2}, \mathrm{Zn}_{\mathrm{Mt} 1}$ and $\mathrm{Zn}_{\mathrm{Mt} 2}$.

\section{Results and Discussion}

\section{Zinc fractionation in soil}

$\mathrm{Zn}$ phases were influenced by the $\mathrm{ZnCl}_{2}$ concen- tration and by the interaction between particle-soil solution interfaces. The $\mathrm{Zn}$ concentration varied according to the $\mathrm{ZnCl}_{2}$ rates applied and was different for the crops, which were evaluated in a proportional distribution (Figures 1 and 2). In general, $\mathrm{Zn}_{\text {res }}$ was the most abundant phase for the highest rate, i.e. $8 \mathrm{mg} \mathrm{kg}^{-1}$, followed by $\mathrm{Zn}_{\mathrm{Oxi}} \mathrm{Zn}_{\text {Exc }} \mathrm{Zn}_{\mathrm{OM}}$ and $\mathrm{Zn}_{\text {Carb }}$ in soil cultivated with rice. $Z n_{\text {res }}$ was also the most expressive phase for soybean cultivation, followed by $\mathrm{Zn}_{\text {Exc' }} \mathrm{Zn}_{\mathrm{Oxi}}=\mathrm{Zn}_{\mathrm{OM}}$ and $\mathrm{Zn}_{\mathrm{Carb}^{\prime}}$ with no difference between the $\mathrm{Zn}_{\mathrm{Oxi}}$ and $\mathrm{Zn}_{\mathrm{OM}}$ proportions. Soil samples treated with $4 \mathrm{mg} \mathrm{kg}^{-1}$ had the following designs: $\mathrm{Zn}_{\text {res }}>\mathrm{Zn}_{\text {Oxi }}>\mathrm{Zn}_{\mathrm{Exc}}>\mathrm{Zn}_{\mathrm{OM}}=\mathrm{Zn}_{\text {Carb }}$ for soil cultivated with rice and $\mathrm{Zn}_{\text {res }}>\mathrm{Zn}_{\mathrm{Oxi}}>\mathrm{Zn}_{\mathrm{Exc}}=$ $\mathrm{Zn}_{\mathrm{OM}}>\mathrm{Zn}_{\mathrm{Carb}}$ for soil cultivated with soybean. Finally, the control samples, without any $\mathrm{Zn}$ addition, were described by $\mathrm{Zn}_{\text {res }}>\mathrm{Zn}_{\text {Oxi }}>\mathrm{Zn}_{\mathrm{OM}}>\mathrm{Zn}_{\text {Exc }}>\mathrm{Zn}_{\text {Carb }}$ for soil cultivated with rice and $\mathrm{Zn}_{\text {res }}>\mathrm{Zn}_{\text {Oxi }}>\mathrm{Zn}_{\mathrm{OM}}>\mathrm{Zn}_{\mathrm{Exc}}=$ $\mathrm{Zn}_{\text {Carb }}$ for soybean.

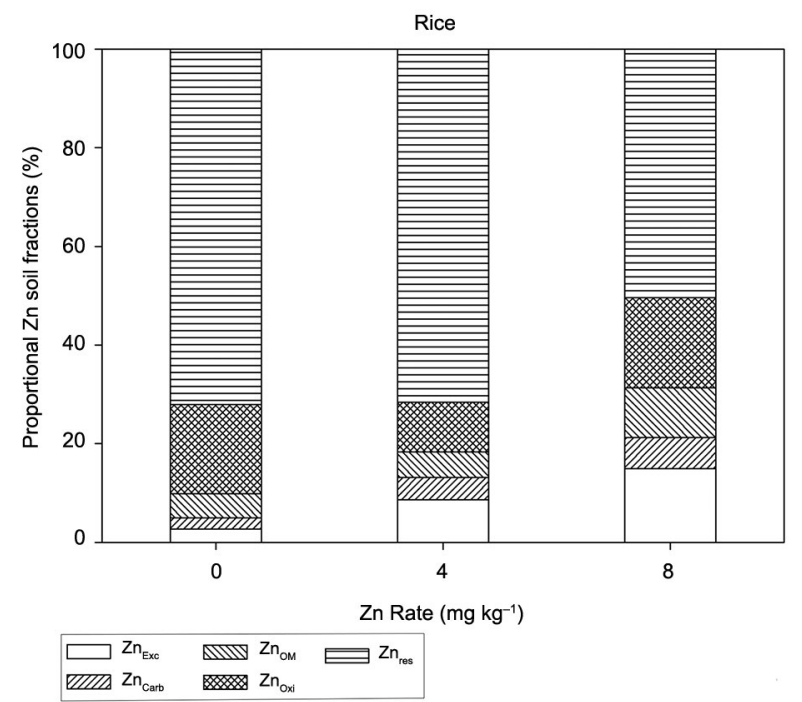

Figure 1 - Zinc fractions distribution affected by $\mathrm{ZnCl}_{2}$ addition in soil cultivated with rice (exchangeable $\mathrm{Zn}, \mathrm{Zn}_{\text {Exc }} ; \mathrm{Zn}$ bound to carbonates, $\mathrm{Zn}_{\text {Carb }}$; $\mathrm{Zn}$ bound to organic matter, $\mathrm{Zn}_{\mathrm{OM}} ; \mathrm{Zn}$ bound to oxides, $\mathrm{Zn}_{\mathrm{Oxi}}$ and residual $\mathrm{Zn}, \mathrm{Zn}_{\text {res }}$. Data are represented by means of quadruplicate.

Table 2 - Sequential extraction procedure: extractants solution, specific condition and extraction phase of soil at each extraction step.

\begin{tabular}{|c|c|c|c|c|}
\hline Steps & Extractant solution & Shaking and centrifuge condition & Other specification & Fraction \\
\hline 1 & $0.1 \mathrm{~mol} \mathrm{~L}^{-1}$ Calcium Chloride & $\begin{array}{l}180 \mathrm{rpm} \text { for } 2 \mathrm{~h} \\
3000 \mathrm{rpm} \text { for } 10 \mathrm{~min}\end{array}$ & room temperature & $\mathrm{Zn}_{\mathrm{Exc}}$ (exchangeable, soluble) \\
\hline 2 & Concentrated Sodium Acetate & $\begin{array}{l}180 \mathrm{rpm} \text { for } 5 \mathrm{~h} \\
3000 \mathrm{rpm} \text { for } 10 \mathrm{~min}\end{array}$ & $\mathrm{pH}$ adjusted to 5 & $\mathrm{Zn}_{\text {Carb }}$ (bound to carbonates) \\
\hline 3 & 5 \% Sodium Hypochlorite & $\begin{array}{l}3000 \mathrm{rpm} \\
10 \mathrm{~min}\end{array}$ & $\begin{array}{l}\mathrm{pH} \text { adjusted to } 8.5 \\
\text { water bath }\left(90^{\circ} \mathrm{C}\right) \text { for } 30 \mathrm{~min}\end{array}$ & $\begin{array}{l}\mathrm{Zn}_{\text {oM }} \text { (oxidisable, bound to organic } \\
\text { matter) }\end{array}$ \\
\hline 4 & $\begin{array}{l}0.2 \mathrm{~mol} \mathrm{~L}^{-1} \text { Ammonium Oxalate } \\
0.2 \mathrm{~mol} \mathrm{~L}^{-1} \text { Oxalic Acid } \\
0.1 \mathrm{~mol} \mathrm{~L}^{-1} \text { Ascorbic Acid }\end{array}$ & $\begin{array}{l}3000 \mathrm{rpm} \\
10 \mathrm{~min}\end{array}$ & $\begin{array}{l}\mathrm{pH} \text { adjusted to } 3 \\
\text { water bath }\left(90^{\circ} \mathrm{C}\right) \text { for } 30 \mathrm{~min}\end{array}$ & $\begin{array}{l}\mathrm{Zn}_{\text {oxir }} \text { (reducible, bound to oxi/ } \\
\text { hydroxides) }\end{array}$ \\
\hline 5 & $\begin{array}{l}\text { Concentrated Nitric Acid and } \\
\text { Hydrochloric acid }\end{array}$ & - & microwave digestion & $\begin{array}{l}\mathrm{Zn}_{\text {res }} \text { (residual, bound to silicate } \\
\text { minerals) }\end{array}$ \\
\hline
\end{tabular}




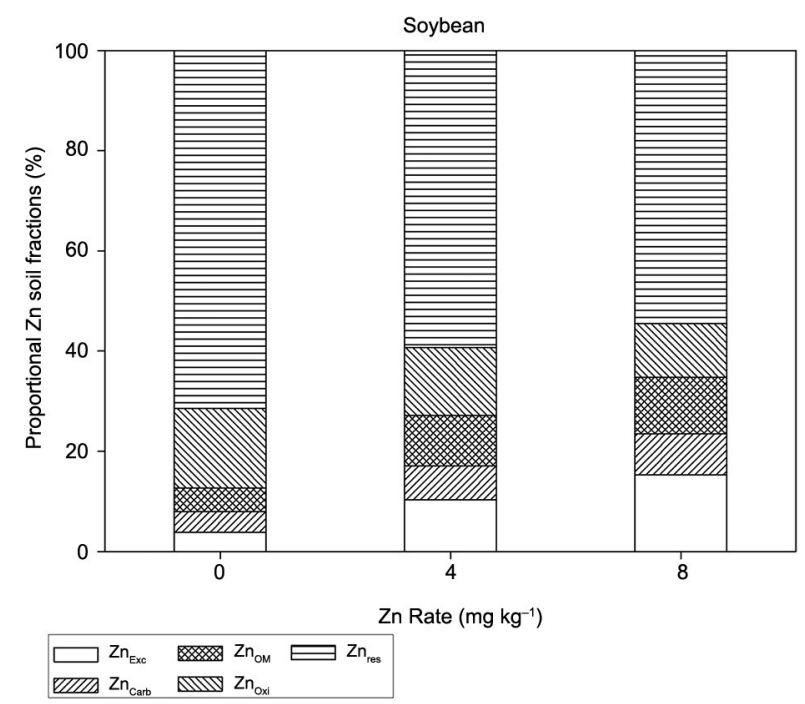

Figure 2 - Zinc fractions distribution affected by $\mathrm{ZnCl}_{2}$ addition in soil cultivated with soybean (exchangeable $\mathrm{Zn}, \mathrm{Zn}_{\mathrm{Exc}} ; \mathrm{Zn}$ bound to carbonates, $\mathrm{Zn}_{\text {Carb }}$; $\mathrm{Zn}$ bound to organic matter, $\mathrm{Zn}_{\mathrm{OM}} ; \mathrm{Zn}$ bound to oxides, $\mathrm{Zn}_{\mathrm{Oxi}}$ and residual $\mathrm{Zn}, \mathrm{Zn}_{\text {res }}$. Data are represented by means of quadruplicate.

$\mathrm{Zn}_{\text {res }}$ was proportionally the highest phase for all $\mathrm{Zn}$ rates in the soil samples cultivated with rice and soybean. Yang et al. (2013) also observed $\mathrm{Zn}$ in the residual phase representing more than $50 \%$ of total $\mathrm{Zn}$ in soil associated with $\mathrm{Zn}$ retention in crystalline structures which characterizes a stable phase (Fuentes et al., 2008). Under an expressive weathering soil condition, $\mathrm{Zn}^{2+}$ metallic ions bound favorably to the broken edges of 1:1 clay minerals, which hinder the $\mathrm{Zn}$ bioavailability in soil solution since ions are unavailable due to the adsorption to mineral soil components (Garcia et al., 2008).

Specific binds with $\mathrm{Fe}$ or Al hydroxides characterize the $\mathrm{Zn}_{\text {Oxi }}$ phase, as they involve high energy adsorption and prevent $\mathrm{Zn}$ availability in the soil solution (Kalbasi et al., 1978; Cavallaro and McBride, 1984). Leleyter et al. (2012) reported $\mathrm{Zn}$ binds expressively to oxides for two types of soil samples: from a privative garden $100 \mathrm{mg}$ $\mathrm{kg}^{-1} \mathrm{Zn}$ ) and from an agricultural soil (50 $\mathrm{mg} \mathrm{kg}^{-1} \mathrm{Zn}$ ). A comparison between $\mathrm{Zn}$ behavior in soil fractions and $\mathrm{ZnCl}_{2}$ rates applied to soil (Figures $3 \mathrm{~A}, \mathrm{~B}$ and $4 \mathrm{~A}, \mathrm{~B}$ ) revealed no differences $\mathrm{Zn}_{\text {res }}$ and $\mathrm{Zn}_{\text {Oxi }}$ for the crops due to the addition of the saline source. Soil particles expressively bonds $\mathrm{Zn}_{\text {res }}$ and $\mathrm{Zn}_{\text {Oxi }}$ phases, which are considered "non-available Zn for plants". Usually some forms of Zn in soil are not available to rice: $\mathrm{Zn}$ tightly bound to insoluble soil organic matter, Zn tightly adhering to soil particle surfaces (e.g. iron oxides, carbonates, or cation exchange sites), precipitated $\mathrm{Zn}$ (e.g. with sulfides or carbonates), or $\mathrm{Zn}$ in structural minerals (Impa, 2012).

$\mathrm{Zn}_{\text {Exc' }} \mathrm{Zn}_{\text {Carb }}$ and $\mathrm{Zn}_{\mathrm{OM}}$ phases, which may interact by solubilization and-or availability, promote greater mobility in the soil solution for plants. Only a small fraction of $\mathrm{ZnCl}_{2}$ became available to plants in both samples, even at higher rates (Figures $3 \mathrm{~A}$ and $4 \mathrm{~A}$ ). $\mathrm{Zn}_{\mathrm{Exc}^{\prime}}$ which is weakly bound in soil particles, but became available easily in the soil solution through exchanges of chemical bonds. In general, the concentration of the most labile fractions $\left(\mathrm{Zn}_{\text {Exc }}, \mathrm{Zn}_{\text {Carb }}\right.$ and $\left.\mathrm{Zn}_{\mathrm{OM}}\right)$ increased as a function of the $\mathrm{Zn}$ rates applied to the soil cultivated with rice or soybean. The average concentration of extracted $\mathrm{Zn}_{\text {Exc }}$ (Figure 3A) ranged from 0.40 (control) to $2.72 \mathrm{mg} \mathrm{kg}^{-1}\left(8 \mathrm{mg} \mathrm{kg}^{-1}\right.$ rate) in the soil cultivated with rice, which demonstrates how the applied rates increases $\mathrm{Zn}$ in the exchangeable fraction. Similarly, in the soil cultivated with soybean, the concentration ranged from 0.50 (control) to $2.78 \mathrm{mg} \mathrm{kg}^{-1}$ (8 $\mathrm{mg} \mathrm{kg}^{-1}$ rate), which shows slightly higher values (Figure 4A). Yang et al. (2013) found similar results for nonagricultural (82.7 $\mathrm{mg} \mathrm{kg}^{-1} \mathrm{Zn} ; \mathrm{pH} 7.85$ ) and agricultural soil samples (157 $\mathrm{mg} \mathrm{kg}^{-1}$; $\mathrm{pH} 7.81$ ), i.e. $5 \%$ of $\mathrm{Zn}$ present in the exchangeable fraction, called "weak acid soluble fraction", and they also considered it the most available phase and of higher mobility. In alkaline soils, a low Zn bound to soluble phase was verified (Wu et al., 2010) attributable to the basic conditions (high $\mathrm{pH}$ ) that promote favorable bounds formed between the charges of metals and mineral clays, i.e., oxides and residual phases (Dai, 2006). In another context, Fernández-Calviño et al. (2017) studied fractionation of heavy metals (BCR methodology) in pine bark amended in a soil from mine activities. They found that, in untreated soil, $96 \%$ of $\mathrm{Zn}$ on residual fraction and in soil samples treated with a heavy metals mixture $\left(1.50 \mathrm{mmol} \mathrm{kg} \mathrm{m}^{-1}\right.$ of $\left.\mathrm{Zn}\right)$ presented $88-92 \%$ as soluble fraction and it rose higher with a period of incubation.

The soil-applied $\mathrm{Zn}$ rates modified $\mathrm{Zn}_{\mathrm{Exc}}$ concentrations in soil from rice and soybean cultivation, except for samples from the $4 \mathrm{mg} \mathrm{kg}^{-1}$ rate in the soil cultivated with soybean, which presented similar concentrations to the highest rate samples (Figures $3 \mathrm{~A}$ and $4 \mathrm{~A}$ ). Soil management in the form of fertilization, contributed to the $\mathrm{Zn}$ bioavailability in the exchangeable fraction, since it promotes changes in the chemistry equilibrium between soil solution and particles, although this fraction was not representative in $\mathrm{Zn}_{\mathrm{sum}}$ (eq. 1, Table 3). According to Oliveira et al. (1999), a $20 \mathrm{mg} \mathrm{kg}^{-1} \mathrm{Zn}$ fertilization rate promoted the highest exchangeable fraction attributable to the higher homogeneous distribution in comparison to the other phases evaluated (mainly Mn oxides and amorphous and crystalline Fe oxides).

The $\mathrm{Zn}_{\text {Carb }}$ phase, which is less expressive in acid soils, ranged from 2 to $6 \%$ (of the $\mathrm{Zn}_{\mathrm{suM}}$ ) in soil cultivated with rice (Figure 1), which varies according to the rate applied (Figure 3A). However, higher concentrations were observed in the soil from soybean cultivation (Figure 2), probably due to the higher $\mathrm{pH}$ of the soil, required for the crop growth ( $\mathrm{pH} 6.2$ after liming). The extractant solution of sodium acetate used in fractionation reacts with the soil solution and solubilizes the functional groups from colloids, which releases $\mathrm{Zn}$ for the soil solution previously associated with acid groups.

The carbonate chemical balance indicates a prevalence of undissociated carbonic acid $\left(\mathrm{H}_{2} \mathrm{CO}_{3}{ }^{\circ}\right)$ in the soil 
Table 3 - Pseudo total zinc extracted from soil $\left(\mathrm{Zn}_{\mathrm{PST}}\right)$ cultivated with rice and soybean, according to USEPA 3051A method; sum of $\mathrm{Zn}$ extracted by fractionation $\left(\mathrm{Zn}_{\text {sum }}\right)$, followed mean values and mean standard error and recovery $\mathrm{Zn}(\mathrm{Rec})$ as a function of the zinc rates added into the soil.

\begin{tabular}{|c|c|c|c|c|c|c|}
\hline \multirow[b]{2}{*}{ Rate } & \multicolumn{3}{|c|}{ Soil from rice cultivation } & \multicolumn{3}{|c|}{ Soil from soybean cultivation } \\
\hline & $Z n_{P S T}$ & $2 n_{\text {SUM }}$ & $\operatorname{Rec}$ & $Z n_{P S T}$ & $2 \mathrm{n}_{\text {SUM }}$ & $\operatorname{Rec}$ \\
\hline \multirow{2}{*}{0} & $\mathrm{m \xi}$ & 20 & $\%$ & 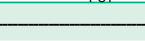 & - & $\%$ \\
\hline & $13.2 \pm 0.7$ & $16.2 \pm 0.6$ & $124 \pm 7$ & $9.5 \pm 0.7$ & $14.6 \pm 0.7$ & $154 \pm 9$ \\
\hline 4 & $13.4 \pm 1.0$ & $18.1 \pm 0.5$ & $137 \pm 8$ & $12.4 \pm 1.2$ & $15.8 \pm 0.9$ & $132 \pm 17$ \\
\hline 8 & $12.1 \pm 0.9$ & $19.3 \pm 2.2$ & $143 \pm 3$ & $12.4 \pm 0.8$ & $17.0 \pm 0.9$ & $127 \pm 15$ \\
\hline
\end{tabular}
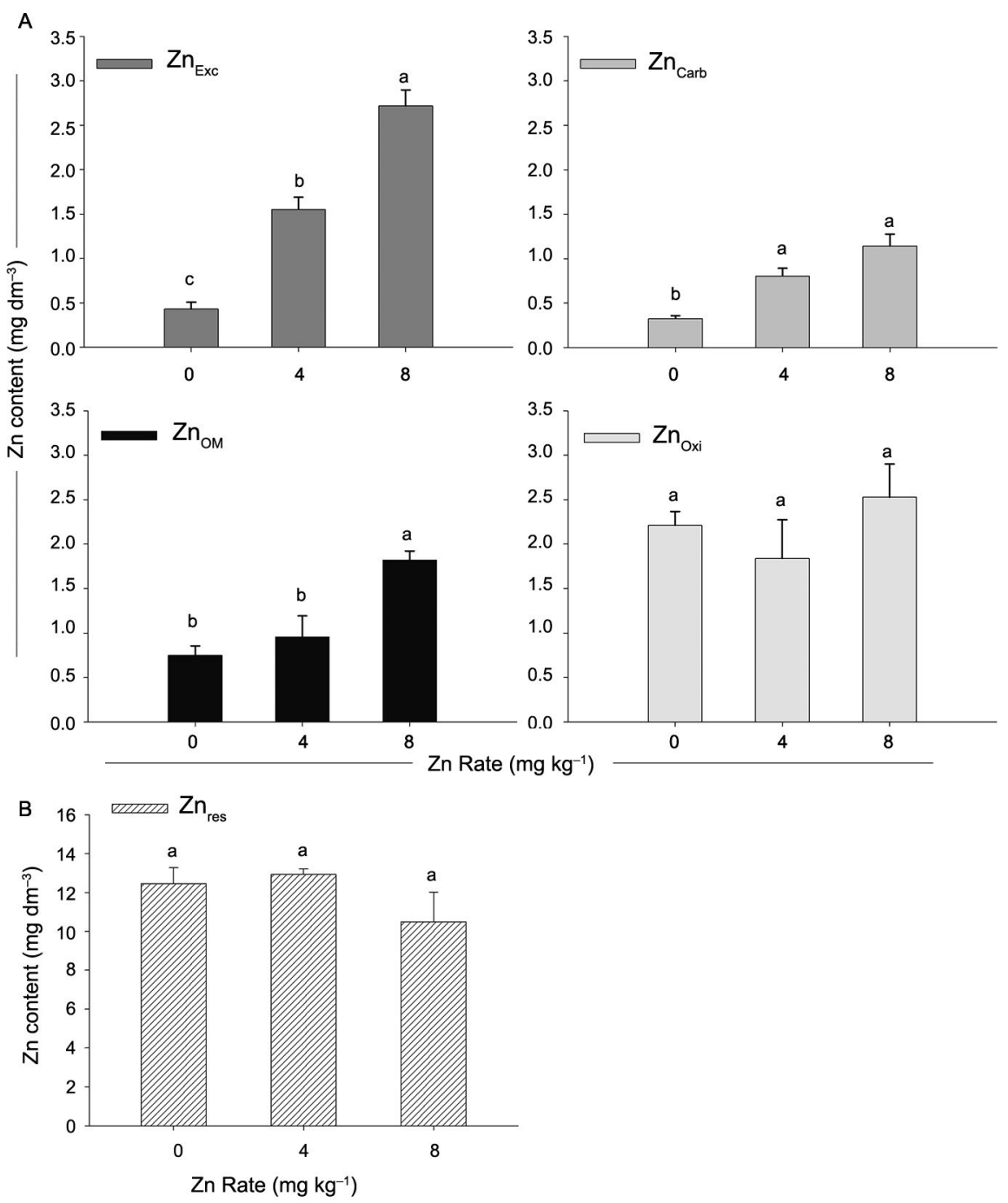

Figure 3 - A) Zinc fractions content extracted from soil cultivated with rice (exchangeable $\mathrm{Zn}, \mathrm{Zn} \mathrm{n}_{\text {Exc }} ; \mathrm{Zn}$ bound to carbonates, $\mathrm{Zn}$ carb $; \mathrm{Zn}$ bound to organic matter, $\mathrm{Zn}_{\mathrm{om}} ; \mathrm{Zn}$ bound to oxides, $\mathrm{Zn}_{0 \mathrm{xi}}$ ) and $\mathrm{B}$ ) residual $\mathrm{Zn}, \mathrm{Zn}_{\text {res }}$. The bars with lower case letters are significant (Tukey's multiple range test, $p<0.05)$. Data are represented by means \pm standard errors.

$\mathrm{pH}$, which explains the low proportion of $\mathrm{Zn}$ bound to carbonates $\left(\mathrm{CO}_{3}^{-2}\right)$ (see the diagram proposed by Lindsay, 1979). Under higher $\mathrm{pH}$ the bicarbonate $\left(\mathrm{HCO}_{3}^{-}\right)$species precipitated as $\mathrm{Zn}\left(\mathrm{HCO}_{3}\right)_{2}$ prevails which results in a higher contribution of the $\mathrm{Zn}_{\text {Carb }}$ fraction. The $\mathrm{Zn}_{\text {Carb }}$ fraction is also associated with carbonate minerals (e.g. calcite) when an isomorphous substitution occurs between
$\mathrm{Ca}^{2+}$ and other divalent metals, as $\mathrm{Zn}^{2+}$ (Auernheimer and Chinchon, 1997). The $\mathrm{pH}$ of the soil cultivated with soybean was 6.1 , which characterizes the predominance of $\mathrm{HCO}_{3}{ }^{-}$activity in the soil solution, whereas the $\mathrm{pH}$ of the soil cultivated with rice was 5.9, which favors the formation of $\mathrm{Zn}\left(\mathrm{HCO}_{3}\right)_{2}$, as shown in the diagram proposed by Lindsay (1979). 

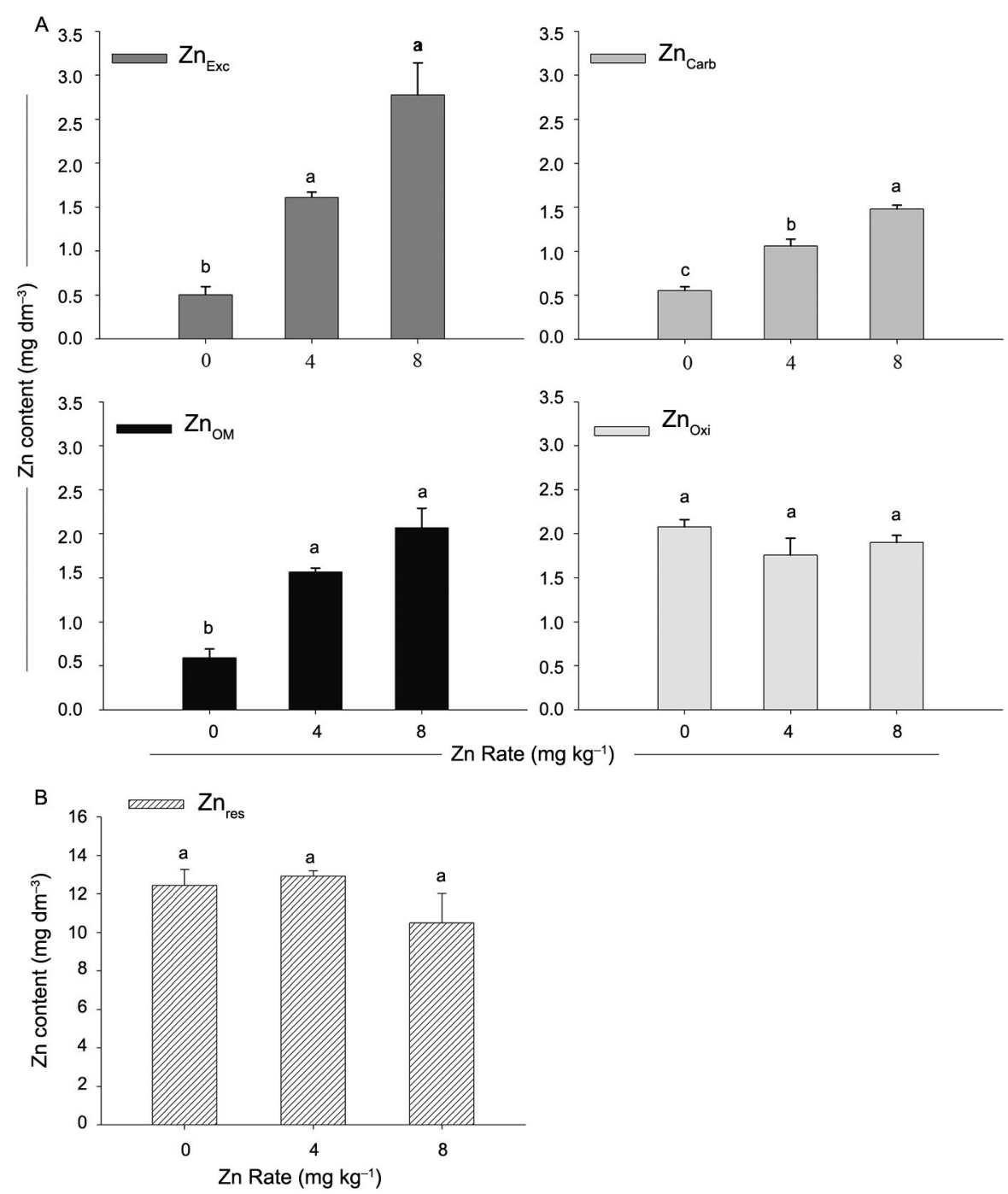

Figure 4 - A) Zinc fractions content extracted from soil cultivated with soybean (exchangeable $Z n, Z n_{E x c} ; Z n$ bound to carbonates, $Z n_{\text {Carb }} ; Z n$ bound to organic matter, $\mathrm{Zn}_{\mathrm{OM}} ; \mathrm{Zn}$ bound to oxides, $\mathrm{Zn}_{\mathrm{Oxi}}$ ) and $\mathrm{B}$ ) residual $\mathrm{Zn}, \mathrm{Zn}_{\text {res }}$. The bars with lower case letters are significant (Tukey's multiple range test, $p<0.05)$. Data are represented by means \pm standard errors.

The concentrations of the $\mathrm{Zn}_{\mathrm{OM}}$ fraction ranged from 5 to $10 \%$ for soil cultivated with rice and from 5 to $11 \%$ for soybean (Figures 1 and 2). The lower abundance of the $\mathrm{Zn}_{\mathrm{OM}}$ fraction is due to the clayey-textured Typic Hapludox used in the experiment, which has a low OM content (Table 1). However, both crops cultivated varied as a function of the applied rates (Figures $3 \mathrm{~A}$ and $4 \mathrm{~A}$ ). The $4 \mathrm{mg} \mathrm{kg}^{-1}$ rate for the soil cultivated with soybean exhibited the same behavior as the $8 \mathrm{mg}$ $\mathrm{kg}^{-1}$; however, the soil cultivated with rice presented no difference between the intermediary rate and the control, which presented a difference only with the highest rate applied. The low concentration of $\mathrm{Zn}$ bound to OM can be attributed to the application of the sodium hypochlorite extractant solution under alkaline conditions, which can result in sub-estimation promoted by the metal precipitation and redistribution of the element in soil phases (Miller et al., 1986; Tu et al., 1994).
The differences in soil phases can be associated with distinct rhizospheres behavior between the crops with the addition of a soluble $\mathrm{Zn}$ source in the soil, which changes the bioavailability condition and results in labile phases in plants. Due to the different $\mathrm{Zn}$ demands between these crops and the root system architecture of Poaceae (rice), and to Fabaceae (soybean), the plants' rhizospheres are different in terms of the root exudates concentrations "as organic acids" that change the rhizosphere $\mathrm{pH}$ and thus the $\mathrm{Zn}$ availability. $\mathrm{Zn}$ is absorbed in the rice and soybean crop by free $\mathrm{Zn}^{2+}$ (aq) and $\mathrm{Zn}$ complexes with organic compound forms (Suzuki et al., 2008). Moreover, $\mathrm{Zn}$ bioavailability is related to soluble inorganic compounds and the weak adsorption of organic and inorganic soil particles which characterize the cation exchange pool.

A $\mathrm{Zn}_{\mathrm{PST}}$ analysis (Table 3) was conducted with a methodology that does not utilize hydrofluoric acid as 
extractant in order to evaluate the pseudo-total $\mathrm{Zn}$ and to compare to $\mathrm{Zn}_{\text {sum }}$. The method was selected because we considered that, in the environmental conditions; there is no solution capable of extracting the pools accessed by hydrofluoric acid.

The recovery was calculated for each support electrolyte rate and ranged from 124 to $143 \%$ for the soil cultivated with rice, and from 127 to $154 \%$ for soybean (Table 3). $\mathrm{Zn}_{\mathrm{sum}}$ was higher than $\mathrm{Zn}_{\mathrm{PST}^{\prime}}$ due to the inclusion of the $Z n_{\text {res }}$ phase in the $\mathrm{Zn}_{\text {sum }}$ calculation (eq. $1)$. Owing to the previously extracted fractions $\left(\mathrm{Zn}_{\mathrm{Exc}}\right.$ $\mathrm{Zn}_{\mathrm{Carb}^{\prime}} \mathrm{Zn}_{\mathrm{OM}}$ and $\mathrm{Zn}_{\mathrm{Oxi}} \mathrm{i}$, the same soil sample used for the obtaining of $\mathrm{Zn}_{\text {res }}$ resulted in more efficient extraction, whereas $\mathrm{Zn}_{\mathrm{PST}}$ was conducted with an unchanged soil sample. Therefore, because of sequential analysis and specificities in the determinations of trace elements such as $\mathrm{Zn}$ close ranges in the recovery above or below $100 \%$ are tolerated. Additionally, we considered that the recovery values are sufficient for the main aims of this study as other similar studies have demonstrated (Colzato et al., 2018).

\section{Interaction of $\mathrm{Zn}$ at the soil-plant system}

The total zinc uptake by plants $\left(\mathrm{Zna}_{\text {total }}\right)$ exhibited positive behavior as a function of the soluble $\mathrm{Zn}$ rates applied to the soil and the interaction between the soil solution and soil compartments as reported by the se-
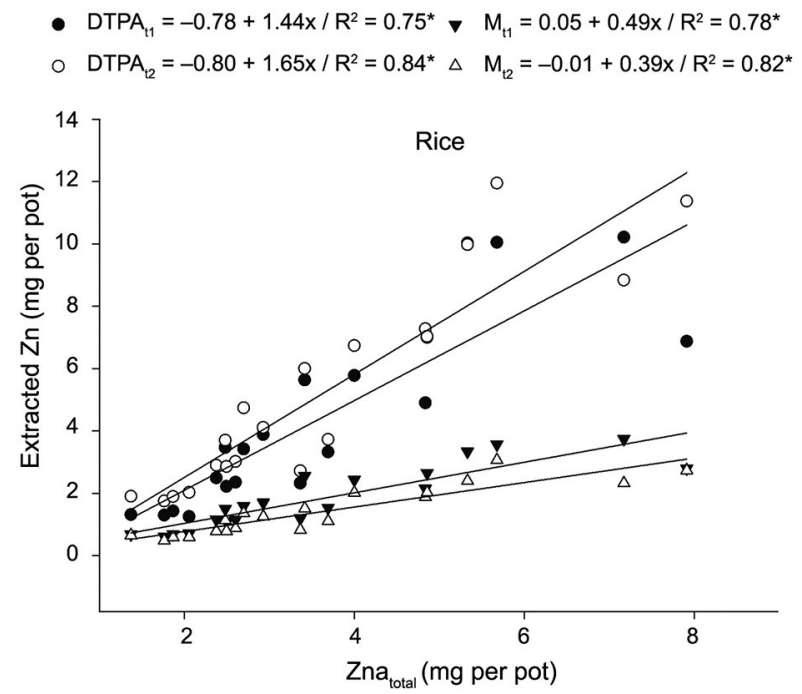

Figure $\mathbf{5}$ - Correlation coefficients between $\mathrm{Zn}$ extracted from soil cultivated with rice by DTPA $\left(\mathrm{Zn}_{\text {DTPAt1 }}\right.$ and $\left.Z \mathrm{n}_{\text {DTPAt2 }}\right)$ and Mehlich-1 $\left(\mathrm{Zn}_{\mathrm{Mt1}}\right.$ and $\left.\mathrm{Zn}_{\mathrm{Mt} 2}\right)$ in two subsamples and the total accumulated $\mathrm{Zn}$ $\left(\mathrm{Zna}_{\text {total }}\right)$ affected by the $\mathrm{ZnCl}$ rates applied (4 and $8 \mathrm{mg} \mathrm{kg}^{-1}$ ). Notes: * Significant $p<0.01$. Extracted $\mathrm{Zn}$ is expressed in mg per pot as regards the total amount of soil used in the experimental units ( $3 \mathrm{~kg}$ per pot) and $\mathrm{Zna}_{\text {total }}$ was expressed in $\mathrm{mg}$ per pot representing the total $\mathrm{Zn}$ absorbed. The following data present the rice dry matter for each treatment ( $Z n$ rates): $45.94 \pm 2.42$ $\left(0 \mathrm{mg} \mathrm{kg}^{-1}\right) ; 49.57 \pm 3.51\left(4 \mathrm{mg} \mathrm{kg}^{-1}\right)$ and $41.57 \pm 5.28(8 \mathrm{mg}$ $\left.\mathrm{kg}^{-1}\right)$ - data are represented by means \pm standard errors. quential extraction analysis. The total $\mathrm{Zn}$ accumulated had increasing correlation for both extractant solutions $\left(\mathrm{Zn}_{\text {DтPA }}\right.$ and $\left.\mathrm{Zn}_{\mathrm{M}}\right)$ with the rates applied and both soil subsamples, $\mathrm{t} 1$ and $\mathrm{t} 2$ (Figures 5 and 6 ). In general, Zn linked with DTPA extraction showed higher values when compared with Mehlich-1 for soil cultivated with both crops especially on $\mathrm{t} 2$ subsamples (flowering). The samples from soil cultivated with rice presented better responses to the extractant solutions than from soybean cultivation.

The application of $\mathrm{ZnCl}_{2}$ rates increases $\mathrm{Zn}$ availability because of the stronger presence of $\mathrm{Zn}$ in the labile fractions, i.e., exchangeable fraction and fractions bound to carbonates and organic matter which could be obtained in the extraction with DTPA and Mehlich-1 solutions. Zn available to rice plants determined by a DTPA extractant solution showed positive correlation for both subsamples $\left(\mathrm{Zn}_{\text {DTPAt1 }}\right.$ and $\left.\mathrm{Zn}_{\text {DTPAt2 }}\right)$ in the soil fractions as presented in Table 4, i.e., $\mathrm{Zn}_{\text {Exc }}$ phase (r: 0.91 and 0.99), $\mathrm{Zn}_{\text {Carb }}(\mathrm{r}: 0.81$ and 0.94$)$ and $\mathrm{Zn}_{\mathrm{OM}}(\mathrm{r}: 0.55$ and 0.59$)$.

$\mathrm{Zn}$ available (DTPA) to soybean plants also correlated with the same fractions, i.e., $\mathrm{Zn}_{\mathrm{Exc}}(\mathrm{r}: 0.93$ and 0.96), $\mathrm{Zn}_{\text {Carb }}\left(\mathrm{r}: 0.83\right.$ and 0.82 ) and $\mathrm{Zn}_{\mathrm{OM}}$ (r: 0.76 for both), (Table 5). Correlations between $\mathrm{Zn}_{\text {DTPAt1 }}$ and $\mathrm{Zn}_{\text {DTPAt2 }}$ subsamples in $\mathrm{Zn}_{\mathrm{Oxi}}, \mathrm{Zn}_{\text {res }}$ fractions were not significant. As regards $\mathrm{Zn}_{\mathrm{PST}^{\prime}}$ no significance (to rice) or low correlation (r: 0.49 in $\mathrm{t} 2$, to soybean) was observed (Table 4 and 5 )

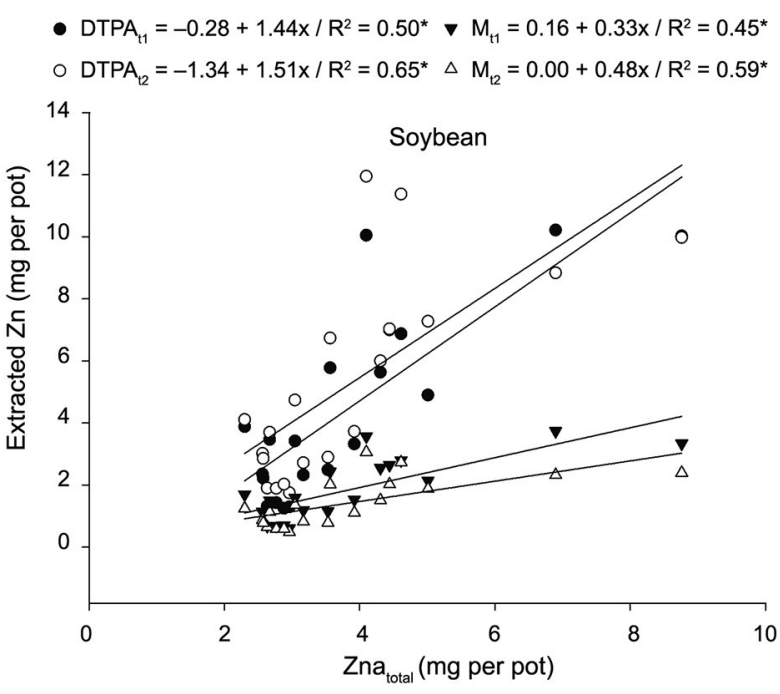

Figure 6 - Correlation coefficients between $\mathrm{Zn}$ extracted from soil cultivated with soybean by DTPA ( $\mathrm{Zn}_{\text {DTPAt1 }}$ and $\left.\mathrm{Zn}_{\text {DTPAt } 2}\right)$ and Mehlich-1 $\left(\mathrm{Zn}_{\mathrm{Mt1}}\right.$ and $\left.\mathrm{Zn}_{\mathrm{Mt2}}\right)$ in two sub-samples and the total accumulated $\mathrm{Zn}$ $(\mathrm{Zna}$ total $)$ affected by the $\mathrm{ZnCl}_{2}$ rates applied (4 and $8 \mathrm{mg} \mathrm{kg}^{-1}$ ). Notes: * Significant $p<0.01$. Extracted $\mathrm{Zn}$ is expressed in $\mathrm{mg}$ per pot regarding the total amount of soil used in the experimental units ( $3 \mathrm{~kg}$ per pot) and $\mathrm{Zna}_{\text {total }}$ was expressed in $\mathrm{mg}$ per pot representing the total $\mathrm{Zn}$ absorbed. The following data present the rice dry matter for each treatment ( $\mathrm{Zn}$ rates): $66.17 \pm 5.15$ $\left(0 \mathrm{mg} \mathrm{kg}^{-1}\right) ; 62.55 \pm 3.90\left(4 \mathrm{mg} \mathrm{kg}^{-1}\right)$ and $59.80 \pm 2.91(8 \mathrm{mg}$ $\left.\mathrm{kg}^{-1}\right)$ - data are represented by means \pm standard errors. 
Table 4 - Pearson's correlation coefficients $(r)$ for the variable response for soil cultivated with rice.

\begin{tabular}{|c|c|c|c|c|c|c|c|c|c|c|c|}
\hline & $Z n a_{\text {total }}$ & $\mathrm{Zn}_{\text {DTPAt1 }}$ & $\mathrm{Zn}_{\mathrm{Mt1}}$ & $\mathrm{Zn}_{\text {DTPAt2 }}$ & $\mathrm{Zn}_{\mathrm{Nt} 2}$ & $Z n_{\text {Exc }}$ & $\mathrm{Zn}_{\text {Carb }}$ & $\mathrm{Zn}_{\mathrm{OM}}$ & $\mathrm{Zn}_{0 \mathrm{xi}}$ & $Z n_{\text {res }}$ & $\mathrm{Zn}_{\text {PST }}$ \\
\hline $\mathrm{Zna}_{\text {total }}$ & 1 & 0.93 & 0.94 & 0.90 & 0.91 & 0.89 & 0.82 & 0.56 & $0.19 \mathrm{~ns}$ & $-0.05 \mathrm{~ns}$ & $-0.03 \mathrm{~ns}$ \\
\hline $\mathrm{Zn}_{\text {DTPAt1 }}$ & & 1 & 0.99 & 0.94 & 0.94 & 0.91 & 0.81 & $0.55^{1}$ & $0.20 \mathrm{~ns}$ & $0.13 \mathrm{~ns}$ & $0.05 \mathrm{~ns}$ \\
\hline $\mathrm{Zn}_{\mathrm{Mt1}}$ & & & 1 & 0.94 & 0.95 & 0.91 & 0.82 & $0.52^{1}$ & $0.19 \mathrm{~ns}$ & $0.12 \mathrm{~ns}$ & $0.05 \mathrm{~ns}$ \\
\hline $\mathrm{Zn}_{\text {DTPAt2 }}$ & & & & 1 & 0.99 & 0.99 & 0.94 & 0.59 & $0.12 \mathrm{~ns}$ & $0.03 \mathrm{~ns}$ & $0.13 \mathrm{~ns}$ \\
\hline $\mathrm{Zn}_{\text {Mt2 }}$ & & & & & 1 & 0.96 & 0.92 & 0.57 & $0.06 \mathrm{~ns}$ & $0.08 \mathrm{~ns}$ & $0.18 \mathrm{~ns}$ \\
\hline$Z n_{\text {Exc }}$ & & & & & & 1 & 0.93 & 0.60 & $0.15 \mathrm{~ns}$ & $-0.02 \mathrm{~ns}$ & $0.09 \mathrm{~ns}$ \\
\hline $\mathrm{Zn}_{\text {Carb }}$ & & & & & & & 1 & $0.53^{1}$ & $-0.08 \mathrm{~ns}$ & $-0.07 \mathrm{~ns}$ & $0.08 \mathrm{~ns}$ \\
\hline $\mathrm{Zn}_{\mathrm{OM}}$ & & & & & & & & 1 & $0.29 \mathrm{~ns}$ & $0.07 \mathrm{~ns}$ & $0.20 \mathrm{~ns}$ \\
\hline $\mathrm{Zn}_{0 \mathrm{xi}}$ & & & & & & & & & 1 & $-0.08 \mathrm{~ns}$ & $-0.25 \mathrm{~ns}$ \\
\hline $\mathrm{Zn}_{\text {res }}$ & & & & & & & & & & 1 & $0.55 \mathrm{~ns}$ \\
\hline $\mathrm{Zn}_{\mathrm{PST}}$ & & & & & & & & & & & 1 \\
\hline
\end{tabular}

Notes: $r=$ significant correlations $(p<0.01)$, values followed by ${ }^{1}$ significant correlations $(p<0.05)$ and values followed by ns $=$ there is no significance $(p>0.05)$.

Table 5 - Pearson's correlation coefficients $(r)$ for the variable response for soil cultivated with soybean.

\begin{tabular}{|c|c|c|c|c|c|c|c|c|c|c|c|}
\hline & $Z^{n} a_{\text {total }}$ & $\mathrm{Zn}_{\text {DTPAt1 }}$ & $\mathrm{Zn}_{\mathrm{Mt1}}$ & $\mathrm{Zn}_{\text {DTPAt2 }}$ & $\mathrm{Zn}_{\mathrm{Mt} 2}$ & $Z n_{\text {Exc }}$ & $\mathrm{Zn}_{\text {Carb }}$ & $\mathrm{Zn}_{\mathrm{OM}}$ & $Z n_{0 x i}$ & $Z n_{\text {res }}$ & $Z n_{P S T}$ \\
\hline $\mathrm{Zna}_{\text {total }}$ & 1 & 0.82 & 0.79 & 0.80 & 0.78 & 0.78 & 0.62 & $0.45^{1}$ & $-0.06 \mathrm{~ns}$ & $-0.20 \mathrm{~ns}$ & $0.55^{1}$ \\
\hline $\mathrm{Zn}_{\text {DTPAt1 }}$ & & 1 & 0.98 & 0.98 & 0.98 & 0.93 & 0.83 & 0.76 & $-0.11 \mathrm{~ns}$ & $-0.19 \mathrm{~ns}$ & $0.45 \mathrm{~ns}$ \\
\hline $\mathrm{Zn}_{\mathrm{Mt1}}$ & & & 1 & 0.96 & 0.95 & 0.90 & 0.79 & 0.73 & $-0.12 \mathrm{~ns}$ & -0.09 ns & $0.47^{1}$ \\
\hline $\mathrm{Zn}_{\text {DTPAt2 }}$ & & & & 1 & 1.00 & 0.96 & 0.82 & 0.76 & $-0.13 \mathrm{~ns}$ & $-0.20 \mathrm{~ns}$ & $0.49^{1}$ \\
\hline $\mathrm{Zn}_{\mathrm{Mt} 2}$ & & & & & 1 & 0.95 & 0.83 & 0.77 & $-0.14 \mathrm{~ns}$ & -0.23 ns & $0.48^{1}$ \\
\hline $\mathrm{Zn}_{\mathrm{Exc}}$ & & & & & & 1 & 0.80 & 0.66 & $-0.09 \mathrm{~ns}$ & $-0.30 \mathrm{~ns}$ & $0.46^{1}$ \\
\hline $\mathrm{Zn}_{\text {Carb }}$ & & & & & & & 1 & 0.62 & $0.26 \mathrm{~ns}$ & $-0.43 \mathrm{~ns}$ & $0.23 \mathrm{~ns}$ \\
\hline $\mathrm{Zn}_{\text {oM }}$ & & & & & & & & 1 & $-0.35 \mathrm{~ns}$ & $-0.04 \mathrm{~ns}$ & $0.20 \mathrm{~ns}$ \\
\hline$Z n_{0 x i}$ & & & & & & & & & 1 & $-0.48 \mathrm{~ns}$ & -0.50 \\
\hline $\mathrm{Zn}_{\text {res }}$ & & & & & & & & & & 1 & $0.06 \mathrm{~ns}$ \\
\hline $\mathrm{Zn}_{\mathrm{PST}}$ & & & & & & & & & & & 1 \\
\hline
\end{tabular}

which suggests although the three fractions $\left(\mathrm{Zn}_{\mathrm{Oxi}^{\prime}} \mathrm{Zn}_{\mathrm{res}^{\prime}}\right.$ $\mathrm{Zn}_{\mathrm{PST}}$ ) are proportionally higher, they do not represent the $\mathrm{Zn}$ absorption by the plant system because they express lower lability. $\mathrm{Zn}_{\text {Oxi }}$ and $\mathrm{Zn}_{\text {res }}$ fractions are hardly bioavailable, despite the environmental condition variations simulated by different extractants and conditions used in the fractionation methodology.

Mehlich-1 extractant was efficient in the assay of Zn availability to plants. High significant correlations were observed for rice in both subsamples in the following fractions: $\mathrm{Zn}_{\mathrm{Exc}}(\mathrm{r}: 0.91$ and 0.96$), \mathrm{Zn}_{\text {Carb }}(\mathrm{r}: 0.82$ and 0.92 ) and $\mathrm{Zn}_{\mathrm{OM}}$ (r: 0.52 and 0.57) phases, whereas for soybean, the correlations were $\mathrm{Zn}_{\mathrm{Exc}}(\mathrm{r}$ : 0.90 and 0.95), $\mathrm{Zn}_{\text {Carb }}(\mathrm{r}: 0.79$ and 0.83$)$ and $\mathrm{Zn}_{\mathrm{OM}}(\mathrm{r}: 0.73$ and 0.77$)$ in $\mathrm{t} 1$ and $t 2$, respectively (Tables 4 and 5). The presence of $\mathrm{Zn}$ in the oxides and residual phases did not explain the $\mathrm{Zn}$ availability, as was observed in the DTPA solution.

Oliveira et al. (1999) found exchangeable $\mathrm{Zn}, \mathrm{Zn}$ bound to organic matter and $\mathrm{Zn}$ bound to manganese oxide fractions in soils treated with $20 \mathrm{mg} \mathrm{Zn} \mathrm{kg}^{-1}$ highly correlated with DTPA extraction. The same phases and
Zn linked crystalline iron oxides correlated with M1 $p<$ 0.01). The $\mathrm{Zn}_{\mathrm{OM}}$ fraction exhibited an expressed distinct behavior between the crops in correlation with the extractants. Soybean plants have higher access to available $\mathrm{Zn}$ bound to organic matter than rice plants, especially at the 4 and $8 \mathrm{mg} \mathrm{kg}^{-1}$ rates (Figures $3 \mathrm{~A}$ and $4 \mathrm{~A}$ ). This result can be attributed to the protonation and deprotonation in functional groups of organic matter, which may favor binds with $\mathrm{Zn}^{2+}$ initially available in the soil solution. Since the management of soil $\mathrm{pH}$ is necessarily different for rice and soybean, the responses may be different. Cheng et al. (2005) and Shi et al. (2008) also addressed the difficulty in assigning the $\mathrm{Zn}$ absorption from organic matter $\mathrm{Zn}$ complexes, which may or may not become available.

This study may assemble important information about the soil-applied $\mathrm{Zn}$ management especially in tropical soils such as a Typic Hapludox. The incorporation of $\mathrm{Zn}$ in soil increases $\mathrm{Zn}$ interaction with the colloid particles which decreases its bioavailability in soil. Therefore, it is required to assay other fertilization 
techniques, e.g. fertilizer granules with coating or foliar $\mathrm{Zn}$ application, in order to increase the agronomic efficiency of available $\mathrm{Zn}$ for plants.

\section{Conclusions}

The addition of a soluble source $\left(\mathrm{ZnCl}_{2}\right)$ to clayeytextured Typic Hapludox samples cultivated with rice or soybean increased the $\mathrm{Zn}$ concentration in the labile fractions in the following order: exchangeable $\mathrm{Zn}, \mathrm{Zn}$ bound to organic matter and $\mathrm{Zn}$ bound to carbonates. Such fractions had high positive correlation with total $\mathrm{Zn}$ accumulated in rice and soybean plants. $\mathrm{Zn}$ extracted by DTPA $\left(\mathrm{Zn}_{\text {DTPAt } 1}\right.$ and $\left.\mathrm{Zn}_{\text {DTPA } 2}\right)$ and Mehlich-1 $\left(\mathrm{Zn}_{\mathrm{Mt} 1}\right.$ and $\mathrm{Zn}_{\mathrm{Mt} 2}$ ) correlated positively with $\mathrm{Zn}$ in labile fractions in the soil, which indicates its bioavailability. In contrast, $\mathrm{Zn}$ bound to oxides and residual $\mathrm{Zn}$ present in a high proportion in the soil did not change with increasing $\mathrm{Zn}$ rates. Such fractions correlated neither to the total $\mathrm{Zn}$ accumulated in plants, nor to DTPA and Mehlich-1 extractants, which shows the unavailability of $\mathrm{Zn}$ associated with the $\mathrm{Zn}$ bound to the recalcitrant fractions. The interaction of $\mathrm{Zn}$ with the different soil phases is a relevant key to the assessment of its bioavailability and uptake by plants which varies according to the $\mathrm{ZnCl}_{2}$ concentration applied to soil as a supporting electrolyte.

\section{Acknowledgments}

The authors acknowledge CAPES (Coordenação de Aperfeiçoamento de Pessoal de Nível Superior) for the Master's Degree scholarship for the first author and the Universidade de São Paulo for providing laboratory facilities for the experiments.

\section{Authors' Contributions}

Conceptualization: Leite, C.M.C.; Muraoka, T.; Alleoni, L.R.F. Data acquisition: Leite, C.M.C.; Muraoka, T.; Colzato, M. Data analysis: Leite, C.M.C.; Muraoka, T.; Alleoni, L.R.F. Design of methodology: Leite, C.M.C.; Muraoka, T.; Alleoni, L.R.F. Software development: Leite, C.M.C. Writing and editing: Leite, C.M.C.; Muraoka, T.; Colzato, M.; Alleoni, L.R.F.

\section{References}

Abreu, C.A.; Lopes, A.S.; Santos, G.C.G. 2007. Micronutrients $=$ Micronutrientes. p. 645-736. In: Novais, R.F.; Alvarez, V.H.; Barros, N.F.; Fontes, R.L.F.; Cantarutti, R.B.; Barros, N.F.; Fontes, R.L.F.; Neves, J.C.L., eds. Soil fertility $=$ Fertilidade do solo. Sociedade Brasileira de Ciência do Solo, Viçosa, MG, Brazil (in Portuguese).

Alexakis, D. 2011. Diagnosis of stream sediment quality and assessment of toxic element contamination sources in East Attica, Greece. Environmental Earth Science 63: 1369-1383.

Alloway, B.J. 1995. Heavy Metals in Soils. 2ed. Blackie Academic \& Professional, London, UK.
Asami, T.; Kubota, M.; Orikasa, K. 1995. Distribution of different fractions of cadmium, zinc, lead and copper in unpolluted and polluted soils. Water, Air, \& Soil Pollution 83: 187-194.

Auernheimer, C.; Chinchon, S. 1997. Calcareous skeletons of sea urchins as indicators of heavy metals pollution. Environmental Geology 29: 78-83.

Cabral, A.R.; Lefebvre, G. 1998. Use of sequential extraction in the study of heavy metal retention by silty soils. Water, Air, \& Soil Pollution 102: 329-344.

Camargo, O.A.; Moniz, A.C.; Jorge, J.A.; Valadares, J.M. 1986. Methods of chemical, mineralogical and physical analysis of soils used in the Instituto Agronômico, Campinas, State of São Paulo, Brazil. Instituto Agronômico, Campinas, SP, Brazil (in Portuguese, with abstract in English).

Cantarella, H.; Furlani, P.R. 1997. Upland rice = Arroz de sequeiro. p. 48-49. In: van Raij, B.; Cantarella, H.; Quaggio, J.A.; Furlani, A.M.C., eds. Fertilization and liming recommendations for São Paulo State $=$ Recomendações de adubação e calagem para o Estado de São Paulo. 2ed. Instituto Agronômico, Campinas, SP, Brazil (Boletim Técnico, 100) (in Portuguese).

Cavallaro, N.; McBride, M.B. 1984. Zinc and copper sorption and fixation by an acid soil clay: effect of selective dissolutions. Soil Science Society of America Journal 48: 1050-1055.

Cheng, T.; Champhelaere, K.; Lofts, S.; Janssen, C.; Allen, H.E. 2005. Measurement and computation of zinc binding to natural dissolved organic matter in European surface waters. Analytica Chimica Acta 542: 230-239.

Cloquet, C.; Carignan, J.; Lehmann, M.F.; Vanhaecke, F. 2008. Variations in the isotopic composition of zinc in the natural environment and the use of zinc isotopes in biogeosciences: a review. Analytical and Bioanalytical Chemistry 390: 451-463.

Colzato, M.; Alleoni, L.R.F.; Kamogawa, M.Y. 2018. Cadmium sorption and extractability in tropical soils with variable charge. Environmental Monitoring and Assessment 190: 345.

Dai, S.G. 2006. Environmental Chemistry. 2ed. Higher Education Press, Beijing, China.

Dobermann, A.; Fairhurst, T.H. 2000. Nutrient Disorders and Nutrient Management. International Plant Nutrition Institute, Peachtree Corners, GA, USA.

Empresa Brasileira de Pesquisa Agropecuária [EMBRAPA]. 1997. Manual for Methods of Soil Analysis = Manual de métodos de análise de solo. Embrapa-Centro Nacional de Pesquisa de Solos, Rio de Janeiro, RJ, Brazil (in Portuguese).

Fernández-Calviño, D.; Cutillas-Barreiro, L.; Paradelo-Núñez, R.; Nóvoa-Muñoz, J.C.; Fernández-Sanjurjo, M.J.; ÁlvarezRodríguez, E.; Núñez-Delgado, A.; Arias-Estévez, M. 2017. Heavy metals fractionation and desorption in pine bark amended mine soils. Journal of Environmental Management 192: 79-88.

Fontes, M.P.F; Alleoni, L.R.F. 2006. Electrochemical attributes and availability of nutrients, toxic elements, and heavy metals in tropical soils. Scientia Agricola 63: 589-608.

Fuentes, A.; Lioréns, M.; Sáez, J.; Isabel, A.M.A.; Ortuño, J.F.; Meseguer, V.F. 2008. Comparative study of six different sludges by sequential speciation of heavy metals. Bioresource Technology 99: 517-525.

Frassinetti, S.; Bronzetti, G.; Caltavuturo, L.; Cini, M.; Croce, C.D. 2006. The role of zinc in life: a review. Journal of Environmenal Pathology, Toxicology, and Oncology 25: 579-610. 
Garcia, G.; Penas, J.M.; Manteca, J.I. 2008. Zn mobility and geochemistry in surface sulfide mining soils from SE Spain. Environmental Research 106: 333-339.

Guadalix, M.E.; Pardo, M.T. 1995. Zinc sorption by acidic tropical soils as affected by cultivation. Journal of Soil Science 46: 317322.

Gismera, M.J.; Lacal, J.; Silva, P.; Garcia, R.; Sevilla, M.T.; Procópio, J.R. 2004. Study of metal fractionation in river sediments: a comparison between kinetic and sequential extraction procedures. Environmental Pollution 227: 175-182.

Impa, S.M.; Sarah, E.; Johnson, B. 2012. Mitigating zinc deficiency and achieving high grain $\mathrm{Zn}$ in rice through integration of soil chemistry and plant physiology research. Plant Soil 361: 3-41.

Kalbasi, M.G.; Racz, J.; Loewen-Rudgers, L.A. 1978. Mechanism of $\mathrm{Zn}$ adsorption by iron and aluminum oxides. Soil Science 125: 146-150.

Leleyter, L.; Rousseau, C.; Biree, A.L.; Baraud, F. 2012. Comparison of EDTA, $\mathrm{HCl}$ and sequential extraction procedures, for selected metals $(\mathrm{Cu}, \mathrm{Mn}, \mathrm{Pb}, \mathrm{Zn})$, in soils, riverine and marine sediments. Journal of Geochemical Exploration 116-117: 51-59.

Lindsay, W.L.; Norvell, W.A. 1978. Development of a DTPA soil test for zinc, iron, manganese and cooper. Soil Science Society of America Journal 42: 421-428.

Lindsay, W.L. 1979. Chemical Equilibria in Soils. John Wiley, New York, NY, USA.

Malavolta, E. 1980. Elements of Plant Nutrition = Elementos de Nutrição de Plantas. Agronômica Ceres, São Paulo, SP, Brazil (in Portuguese).

Miller, W.P.; Martens, D.C.; Zelazny, L.W. 1986. Effect of sequence in extraction of trace metals from soils. Soil Science Society of America Journal 50: 598-601.

Miyazawa, M.; Pavan, M.A.; Muraoka, T.; Carmo, C.A.F.S.; Melo, W.J. 2009. Chemical analysis of plant tissue $=$ Análise química de tecido vegetal. p. 191-233. In: Silva, F.C., ed. Manual of chemical analyses of soils, plants and fertilizers $=$ Manual de análises químicas de solos, plantas e fertilizantes. Embrapa, Brasília, DF, Brazil (in Portuguese).

Novais, R.F.; Neves, J.C.L.; Barros, N.F. 1991. Experiment under controlled conditions $=$ Ensaio em ambiente controlado. p. 189-254. In: Oliveira, A.J.; Garrido, W.E.; Araújo, J.D.; Lourenço, S., eds. Research methods in soil fertility $=$ Métodos de pesquisa em fertilidade do solo. Embrapa, Brasília, DF, Brazil (in Portuguese).

Oliveira, M.F.G.; Novais, R.F.; Neves, J.C.L.; Vasconcelos, C.A.; Alves, J.C.L. 1999. Relationship between the Zinc available by different extracting solutions and Zinc fractions in soil samples. Revista Brasileira de Ciência do Solo 23: 827-836 (in Portuguese, with abstract in English).

Rauret, G.; López-Sánchez, J.F.; Sahuquillo, A. 1999. Improvement of the BCR three step sequential extraction procedure prior to the certification of new sediment and soil reference materials. Journal of Environmental Monitoring 1: 57-61.

Shi, Z.Q.; Di Toro, D.; Allen, H.E.; Sparks, D.L. 2008. A WHAM: based kinetics model for $\mathrm{Zn}$ adsorption and desorption to soils. Environmental Science \& Technology 42: 5630-5636.
Silveira, M.L.; Alleoni, L.R.F.; O'Connor, G.A.; Chang, A.C. 2006. Heavy metal sequential extraction methods: a modification for tropical soils. Chemosphere 64: 1929-1938.

Spark, K.M.; Wells, J.D. 1995. Characterizing trace metal adsorption on kaolinite. European Journal of Soil Science 46: 633-640.

Stahl, R.S.; James, B.R. 1991. Zinc sorption by B horizon as a function of $\mathrm{pH}$. Soil Science Society of America Journal 55: 1592-1597.

Soil Survey Staff. 1999. Soil Taxonomy: A Basic System of Soil Classification for Making and Interpreting Soil Surveys. 2ed. NRC-USDA, Washington, DC, USA.

Suzuki, M.; Tsukamoto, T.; Inoue, H.; Watanabe, S.; Matsushashi, S.; Tahashi, M.; Nakanishi, H.; Mori, S.; Nishizawa, N.K. 2008. Deoxymugineic acid increases $\mathrm{Zn}$ translocation in $\mathrm{Zn}$ deficient rice plants. Plant Molecular Biology 66: 609-617.

Tessier, A.; Campbell, P.G.C.; Bisson, N.M. 1979. Sequential extraction procedure for the speciation of particulate trace metals. Analytical Chemistry 51: 844-851.

Tiller, K.G.; Gerth, J.; Brümmer, G. 1984. The sorption of Cd, Zn and $\mathrm{Ni}$ by soil clay fractions: procedures for partition of bound forms and their interpretation. Geoderma 34: 1-16.

Trani, P.E.; van Raij, B. 1997. Vegetables = Hortaliças. p. 157-164. In: van Raij, B.; Cantarella, H.; Quaggio, J.A.; Furlani, A.M.C., eds. Fertilization and liming recommendations for São Paulo State $=$ Recomendações de adubação e calagem para o Estado de São Paulo. 2ed. Instituto Agronômico, Campinas, SP, Brazil (Boletim Técnico, 100) (in Portuguese).

Tu, Q.; Shan, X.Q.; Qian, J.; Ni, Z.M. 1994. Trace metal redistribution during extraction of model soils by acetic acid/ sodium acetate. Analytical Chemistry 66: 3562-3598.

United States Environmental Protection Agency [USEPA]. 2007. Method 3051A: microwave assisted acid digestion of sediments, sludges, soils, and oil. Available at: https:/www.epa.gov/sites/ production/files/2015-12/documents/3051a.pdf [Accessed Apr 6, 2018]

van Raij, B.; Andrade, J.C.; Cantarella, H.; Quaggio, J.A. 2001. Chemical analysis to evaluate the fertility of tropical soils = Análise química para avaliação da fertilidade de solos tropicais. Instituto Agronômico, Campinas, SP, Brazil (in Portuguese).

Wu, C.; Lu, L.; Yang, X.; Feng, Y.; Wei, Y.; Hao, H.; Stoffella, P.J.; He, Z. 2010. Uptake, translocation, and remobilization of zinc absorbed at different growth stages by rice genotypes of different $\mathrm{Zn}$ densities. Journal of Agricultural and Food Chemistry 58: 6767-6773.

Yang, S.; Zhou, D.; Yu, H.; Wei, R.; Pan, B. 2013. Distribution and speciation of metals $(\mathrm{Cu}, \mathrm{Zn}, \mathrm{Cd}$, and $\mathrm{Pb})$ in agricultural and non-agricultural soils near a stream upriver from the Pearl River, China. Environmental Pollution 177: 64-70. 